Puede citar este artículo como:

López Gómez, Óscar. «Después de Isabel la Católica: la última rebelión medieval de Toledo». Anales de la Universidad de Alicante. Historia Medieval, N. 18 (2012-2014): 317-346, DOI:10.14198/ medieval.2012-2015.18.11

\title{
DESPUÉS DE ISABEL LA CATÓLICA: LA ÚLTIMA REBELIÓN MEDIEVAL DE TOLEDO
}

\author{
Óscar López Gómez ${ }^{1}$ \\ (Universidad de Castilla-La Mancha)
}

\section{RESUMEN}

Aunque durante la época de los Reyes Católicos los esfuerzos de la monarquía para apaciguar a la población de Toledo habían sido continuos, pues se trataba de un núcleo urbano favorable a los disturbios y los alborotos-como evidenciaban las revueltas ocurridas en 1449 y 1467-, tras el fallecimiento de la reina Isabel en 1504 el orden público de la urbe degeneró rápidamente, al tiempo que renacían antiguas disputas entre las facciones de los Ayala y los Silva. Esto, unido a las presiones del marqués de Villena por hacerse con el control de la urbe, desembocó en un motín a cuyo frente se puso el líder de los Ayala que estaría a punto de arrastrar a Toledo a una conflagración de parcialidades como no se recordaba desde la década de 1470 .

Palabras clave: Conde de Fuensalida, Conde de Cifuentes, Marqués de Villena, Pedro de Castilla, Silva, Ayala, Archiduque Felipe, Fernando el Católico, Comunidades de Castilla.

\section{ABSTRACT}

Although during the time of the Catholic Kings of the monarchy's efforts to pacify the population of Toledo had been continuous, because it was a

1 Doctor en Historia. Departamento de Historia. Facultad de Ciencias de la Educación y Humanidades. Universidad de Castilla-La Mancha. Campus de Toledo. C.e: oslogro@ gmail.com

El presente trabajo se ha realizado en el marco del proyecto: "Impacto urbano, actividad productiva y sociabilidad en las villas y ciudades castellanas del eje económico ToledoBurgos (1450-1520)", del MICINN, HAR2010-15422. 
rebel city -as evidenced by the riots that occurred in 1449 and 1467-, after the death of Queen Elizabeth in 1504 the public order quickly degenerated, while reborn old disputes between factions of the Ayala and Silva. This, coupled with the pressures of the Marquis de Villena to control the city, ended in a revolt led by the leader of the Ayala would be a drag point to a conflagration of Toledo as not recall from the fifteenth century.

Keywords: Conde de Fuensalida, Conde de Cifuentes, Marqués de Villena, Pedro de Castilla, Silva, Ayala, Archiduque Felipe, Fernando el Católico, Comunidades de Castilla

En el presente artículo se intentará reconstruir la complicada secuencia de hechos que en 1505 y 1506 llevarían a Toledo al borde de una rebelión similar a las de 1449 y $1467^{2}$, en pleno siglo XV, cuando la urbe -como escribiera el cronista Alonso de Palencia- sentía "los más ligeros trastornos ocurridos en el reino", y "como salamandra en el fuego" recogía en sí "el pábulo de las rivalidades" y "no sabía vivir si no se alimentaba con el veneno de las discordias". A pesar de la ingente labor pacificadora desarrollada por los Reyes Católicos para someter a la turbulenta población de Toledo ${ }^{3}$, apenas falleció la reina Isabel resurgiría la vieja lucha de bandos entre los Ayala y los Silva. Durante unos meses, a finales de 1506, en Toledo se tendría la sensación de que la urbe estaba condenada a revivir un pasado ominoso que se creía de otras épocas. Grupos armados por las calles, asambleas juramentadas en las viviendas de los principales caballeros, individuos sin dueño nin señor conosçido que venían a la ciudad con intenciones ocultas, un ir y venir de armamento que terminaba en los arsenales acopiados con premura por los líderes de cada parcialidad. No obstante, en 1506 sí hubo una diferencia con respecto al siglo XV que, por más que al principio se considerara menor, a la postre se revelaría básica de cara al desarrollo de un alzamiento de magnitud en contra de la Corona. Estamos refiriéndonos al ideario religioso. En este terreno la tarea pacificadora de los reyes a través de la Inquisición sí había

2 Las primeras referencias publicadas a lo ocurrido en 1506 se deben a Pedro de Alcocer, en una obra publicada en Sevilla en 1872 bajo el título Relación de algunas cosas que pasaron en estos reynos desde que murió la reina Católica doña Isabel hasta que se acabaron las Comunidades en la ciudad de Toledo.

3 Sobre la pacificación desarrollada por los Reyes Católicos para someter Toledo véase: LÓPEZ GÓMEZ, Ó., Los Reyes Católicos y la pacificación de Toledo, Madrid, 2008. Algunas de las ideas argumentadas en ese libro ya se habían planteado en el artículo "Claves del sistema de pacificación ciudadana desarrollado por los Reyes Católicos en Toledo”, en En la España Medieval, 27, Madrid 2004, pp. 165-193. 
tenido un éxito indiscutible, y ese éxito imposibilitaría que la muchedumbre del pueblo se sumase al motín iniciado en 1506 por los Ayala, al contrario de lo que había ocurrido décadas antes.

Al igual que en el siglo XV, el alzamiento contra el rey Fernando de 1506 comenzó con un acto de rebelión de una parçialidad política, pero contrariamente a lo que pasara en aquel siglo la inexistencia de una ideología religiosa que movilizase a la población, que la dividiera entre cristianos buenos (lindos o cristianos viejos) y malos (judaizantes, marranos), impidió que el pueblo se implicara en la revuelta, motivo por el cual ésta fracasó. No en vano, cuando en enero de 1507 la población comenzó a tomar partido por una parcialidad $\mathrm{u}$ otra y el conde de Cifuentes estuvo a punto de ser asesinado por un simple esmolador de tijeras los oligarcas, temerosos de que al final la situación se les escapase de las manos, decidieron concluir su enfrentamiento con premura, mostrando con su actitud que no querían una radicalización del conflicto que habían iniciado y que no estaban dispuestos a permitir que las clases bajas de la ciudad acaparasen el protagonismo, que es lo que ocurriría una década después, entre 1520 y 1522, durante la rebelión de los comuneros, cuando los oligarcas permitiesen ganar influencia a una serie de hombres de la población común que acabarían solapándolos, haciéndose con las riendas del alzamiento. Aun así, lo ocurrido en 1506 dista de parecerse a las Comunidades.

Aunque el motín de 1506 de alguna manera sería una premonición de lo que iba a pasar en 1520, sobre todo en lo referido al miedo de los poderosos a la actuación activa de las clases bajas en una revuelta -una miedo que las circunstancias demostrarían legítimo-, lo que pasó tras la muerte de la reina Isabel la Católica no tiene nada de novedoso; no caben dudas sobre si se trata o no de una rebelión propia de los tiempos modernos, calificativo que muchos de los historiadores más reputados aplican a la hora de referirse a las Comunidades, a las que sí consideran la primera sublevación de la Modernidad $^{4}$. Por contra, el carácter medieval de los disturbios de 1506 resulta

4 José Antonio MARAVALL fue el primero en definir a las Comunidades como la primera revolución moderna en su obra titulada precisamente así: Las Comunidades de Castilla. Una primera revolución moderna, Madrid, 1981 ( $3^{a}$ Edic.). Esta tesis fue seguida por Joseph Pérez en su obra La revolución de las Comunidades de Castilla (1520-1521), Madrid, 1985. A pesar de alguna discrepancia, la tesis que considera a las Comunidades como una primera rebelión propia de la modernidad es aceptada, más allá de los debates teóricos sobre si sería más adecuado calificarla como una revolución o como una simple revuelta. Uno de los autores que en los últimos tiempos ha intentado profundizar en el debate mirándolo desde otro punto de vista ha sido Pablo SÁNCHEZ LEÓN, en su obra Absolutismo y comunidad. El orígenes sociales de la guerra de los comuneros de Castilla, Madrid, 1998. Máximo DIAGO HERNANDO 
evidente, tanto por sus motivaciones como por los mecanismos de actuación que se exhibieron durante su desarrollo. Podría decirse que la de 1506 fue la última asonada medieval que se produce en Toledo, una ciudad que teóricamente por entonces, en el otoño del reinado de los Reyes Católicos, se debería haber mostrado pacífica si nos atenemos a la labor en beneficio de la pas e sosyego que habían apoyado los monarcas desde la década de 1470 . La revuelta de 1506 puso de manifiesto que las cosas no habían salido tal y como la Corona hubiera deseado.

\section{LA GRAN POLÍTICA: DE LA CORTE A TOLEDO}

Tras la muerte de la reina Isabel en 1504 en Castilla se tiene la sensación de que la obra política de los últimos monarcas del Medievo está a punto de desmoronarse ${ }^{5}$. En las Cortes de Toro de 1505, para conseguir el favor de una nobleza que veía en el archiduque de Austria una baza para recuperar su poderío, el rey Católico estableció de forma oficial la figura del mayorazgo, una institución que transformaba en inalienables los bienes acumulados por un noble, para que pasaran a sus herederos en perfecto estado y sin disminución alguna. En la ciudad de Toledo esta medida cayó bien entre los poderosos, pues estaban teniendo problemas a la hora de salvaguardar la posesión de sus bienes por culpa de las herencias, pero aun así el rey no pudo someter a unos hombres cada día más suspicaces ${ }^{6}$.

La reina Isabel había establecido que tras su fallecimiento su marido quedara como el máximo gobernante de Castilla, por más que el trono estuviera en manos de su hija Juana y de su yerno Felipe, el archiduque de Austria. No obstante, la nobleza veía en el rey Fernando a un extranjero, a un aragonés que pretendía reinar sobre las tierras castellanas, y desde 1504 tal visión ominosa se agudizó, sobre todo cuando estuvo claro que el monarca quería seguir con la rígida política de su mujer. El archiduque Felipe también era un extranjero, y sin embargo parecía afín a la nobleza, a la que alentaba en su postura revanchista frente al rey con escritos a sus seguidores, a los que reclamaba auxilio ante su futura labor en el gobierno castellano. Aun no había acudido a Castilla -se hallaba en sus tierras del norte de Europa- cuando

ha hecho un resumen muy acertado sobre las distintas posturas planteadas frente a la rebelión de las Comunidades y sobre los hechos de la misma en su obra Les comunidades di Castiglia (1520-1521). Una rivolta urbana contro la monarchia degli Asburgo, Milán, 2001.

5 FERNÁNDEZ ALBADALEJO, P., "Los Austrias mayores", en su obra Fragmentos de monarquía. Trabajos de historia política, Madrid, 1992, pp. 23-23.

6 PÉREZ, J., Isabel y Fernando. Los Reyes Católicos, Guipúzcoa, 2001, p. 228. 
Felipe emprendió una campaña contra el rey Fernando, si bien éste reaccionó con premura y, seguro de las pretensiones de su yerno (que pretendía alejarle de la política castellana), envió a dos hombres de confianza a Flandes con una doble tarea: ver cómo se hallaba su hija y pedirle una autorización para que su padre hiciera lo que creyese oportuno en los negocios de España. Felipe, empero, mandó encarcelar a los hombres de Fernando, de un rey que ya comenzaba a quedarse sin apoyos en Castilla ${ }^{7}$.

Consciente de su debilidad ante los nobles, el rey Católico realizó una maniobra que iba a generar una enorme polémica. En octubre de 1505, no habiendo transcurrido un año desde la defunción de la reina Isabel, firmó en Blois un tratado con Luis XII, rey de Francia, por el que se concertó su enlace matrimonial con una sobrina de dicho soberano, Germana de Foix. Todo se hizo pensado en la política internacional, con dos objetivos esenciales: concluir el conflicto franco-aragonés sobre Nápoles ${ }^{8}$ y dificultar la estrategia del archiduque de Austria, que pedía colaboración a los franceses para someter al rey Fernando ${ }^{9}$. El pueblo de Castilla, no obstante, no pudo aceptar el matrimonio de su rey y Germana de Foix. Se veía como un desprecio a la memoria de la reina Isabel que invalidaba los deseos de Fernando de intervenir en el gobierno de Castilla, por mucho que éste apelase al testamento de su esposa difunta.

En noviembre de 1505 el rey y unos representantes de Felipe lograron un compromiso en Salamanca, por el que el archiduque y su mujer se comprometían a reinar en colaboración con Fernando el Católico. Se trataba de un acuerdo válido para todos, pero que nunca llegaría a aplicarse; en gran medida porque los partidarios de Felipe no lo permitieron ${ }^{10}$.

En medio de una tensión política en la corte difícil de atajar, los archiduques de Austria desembarcaron en La Coruña en abril de 1506. En su recibimiento el rey Fernando comprobó en primera persona la falta de apoyos

$7 \quad$ La trama del tiempo en que el archiduque Felipe estuvo en España ya fue recogida por Lorenzo de Padilla en su Crónica de Felipe I, llamado el Hermoso, vol. VIII, Madrid, 1864, pp. 5-267.

8 Para lo que se acordó que el hijo de la unión matrimonial se convirtiera en el soberano de la zona italiana, o que Nápoles quedara en manos de Luis XII de no haber descendientes.

9 De hecho, el archiduque no dudaba en apoyar a Luis XII en su disputa con el rey de Aragón por el reino de Nápoles. Sobre estos acontecimientos véase: FERNÁNDEZ ALBADALEJO, P., "Los Austrias mayores...".

10 En la última década se han publicado biografías tanto de Felipe el Hermoso como de Juana la Loca de una gran calidad. Entre ellas podrían destacarse: CALDERÓN, J.M., Felipe el Hermoso, Espasa, Madrid, 2001; ARAM, B., La reina Juana. Gobierno, piedad y dinastía, Madrid, 2001; FERNÁNDEZ ÁLVAREZ, M., Juana la loca. La cautiva de Tordesillas, Madrid, 2001 (15 Edic ${ }^{a}$ ); y PRAWDIN, M., Juana la Loca, Barcelona, 2001. 
que tenía entre la nobleza. Según iba acercándose a su yerno los nobles que le acompañaban se disgregaron; únicamente el duque de Alba se quedó para hacerle compañía. El rey se sintió tan humillado que a los pocos días se fue a Aragón, y más tarde a Nápoles. Mientras, Felipe comenzó a repartir dádivas entre los que le apoyaban. Al señor de Belmonte, un personaje oscuro llamado Juan Manuel de Villena y la Vega, líder principal de la facción felipina, le concedió la posesión del castillo de Burgos y el alcázar de Segovia, de donde fueron expulsados los marqueses de Moya. Como alcaide de la fortaleza de Simancas puso a un flamenco, el señor de La Chaulx, y otorgó la tutela del alcázar de Toledo al marqués de Villena, arrebatándosela a los Silva, quienes no lo toleraron ${ }^{11}$. Por entonces la situación en Toledo era amenazadora. La actitud parcial, apática y mezquina de los jueces, el comportamiento díscolo de la población y el resurgir de viejas rencillas estaban acabando con el orden público $^{12}$. Al igual que en el siglo $\mathrm{XV}$, el nerviosismo y las dudas que proyectaba la corte tendrían una repercusión inminente en la ciudad.

En principio, por su tradición de obediencia a la reina Isabel, la ciudad del Tajo sería una de las que se mantuvieran fieles al rey Católico. Si el valedor del soberano en Castilla era el duque de Alba, en Toledo algunos hombres en cuyas manos estaba la urbe, que debían todo al rey, no dudarían en mantenerse leales a su persona. Se trataba de líderes en una situación de predominio ascendente, como Pedro López de Padilla (padre de Juan de Padilla, futuro líder comunero), Fernando de la Vega o algunos miembros de la familia Guzmán, entre los cuales se había educado el infante Fernando, hijo del rey y hermano del futuro Carlos I de Castilla y Aragón. Todos ellos eran hombres muy próximos a los Silva; hombres que llevados por una situación política y económica favorable, seguros de contar con el respaldo de la realeza, no supieron ver -al igual que no supo verlo la corte- hasta qué punto comenzaba a degenerar el orden público en los años iniciales del siglo XVI.

Ateniéndonos a lo que nos revelan los miles de escritos del Registro General del Sello, la sección más jugosa del Archivo General de Simancas, el ambiente aciago y perturbador en que vivían muchas personas en los albores del siglo XVI por culpa de la violencia y los apuros económicos se vio enrarecido, aún más, después de la muerte de la reina en 1504. Las palabras del historiador sobran a la hora de reflejar el dramatismo del contexto que sufría a diario un buen número de personas. Muertes, endeudamientos, extorsiones, amenazas. Entre la documentación referida a Toledo nunca habían

11 FRANCO SILVA, F, Entre la derrota y la esperanza. Don Diego López Pacheco, marqués de Villena (mediados del siglo XV-1529), Cádiz, 2005, p. 63.

12 AMT, "Este libro es de traslados...", Sección B, nº. 120, fol. 309 r. 
aparecido tantos robos y asesinatos ${ }^{13}$, y lo que es peor: desde hacía tres décadas el delito no aparecía tan enlazado con la política como ahora, a partir de 1504, entre otras causas porque quienes buscaban controlar Toledo tras la defunción de Isabel harían lo posible por desautorizar a Pedro de Castilla, al corregidor que estaba al frente de la urbe por mandato del rey Católico, y con tal objetivo no tendrían reparos a la hora de perpetrar alborotos, ruidos, escándalos e muertes que sembrarían el caos. La violencia fue manejada como un mecanismo de desestabilización institucional con el que se pretendían promover los desórdenes, para que la opinión pública se opusiese al corregidor que apoyaba el soberano. Los enemigos de la reina fallecida allá por los 70 del siglo XV, ahora, a comienzos del XVI, intentarían vengarse, y con tal fin presionaron a la población para que se opusiese el sistema que representaban el rey Católico y Pedro de Castilla. Fundamentalmente fueron dos hombres los que emplearon la violencia para imponer unos nuevos planteamientos, si bien a su lucha se sumarían muchos de los omes poderosos: Diego López Pacheco, marqués de Villena, y Pedro López de Ayala, conde de Fuensalida. A ambos siempre les acompañarían algunos miembros del linaje de los Guzmán y los regidores que eran del marqués, es decir, que apostaban por la entronización de Felipe.

En efecto, por aquel entonces, entre 1505 y 1506, resucitarían rivalidades que estaban fraguándose desde 1454 y más allá en forma de enfrentamiento entre dos bandos ${ }^{14}$ : el de los Ayala, con el conde de Fuensalida y el marqués de Villena al frente, que recibía el apoyo del archiduque Felipe y era contrario al corregidor, a Pedro de Castilla; y el de los Silva, liderado por el conde de Cifuentes y los Ribadeneira, cuyos planteamientos, si bien más cercanos al corregidor, eran ambiguos, aunque indudablemente estaban en contra del deseo del conde de Fuensalida de hacerse con el dominio de la urbe. El rey Católico, en medio de estos frentes, no dudó en dar su apoyo a los Silva movido por el antiguo apego de su parcialidad a la reina Isabel, y porque los Sil-

13 Sería tedioso referir uno a uno la ingente cantidad de casos de agresiones y amenazas que se registran en estos años, sobre todo a partir de 1502 y hasta 1506. Juan Bautista Serrano, por ejemplo, afirmaba que en el llamado Corral de Escaraul había tenido una discusión con Esteban de Brihuega, y que, enfadado con las palabras que le dijo, le dio un golpe que fue mortal (AGS, RGS, 11 de marzo de 1498, fol. 392). Juan de la Torre "el mozo", hijo de Juan de la Torre, Francisco de Salamanca y Diego de Torres asestaron tal paliza a Pedro de Sotis Acevedo que no sobrevivió (AGS, RGS, 1501-V, Granada, 8 de mayo de 1501). Juan Calderón en un enfrentamiento con Diego de Bargas y Alonso de Córdoba asesinó a éste (AGS, RGS, 1501-V, Granada, 31 de mayo de 1501)

14 LÓPEZ GÓMEZ, Ó., Los Reyes Católicos y la pacificación..., pp. 42 y ss. 
va aparentemente eran del corregidor, en el que el rey confiaba ${ }^{15}$. No obstante, el conde de Fuensalida y el marqués de Villena, los principales apoyos de Felipe, consideraban que tras la desaparición de Isabel las circunstancias les permitían recuperar su control sobre Toledo; aquel control que los propios Reyes Católicos les habían arrebatado al derrotar a su partido en la guerra civil de la década de 1470 .

A comienzos de 1505 las posturas estaban claras. El conde de Fuensalida, erigiéndose de nuevo en líder de una parçialidad, dio su apoyo al archiduque de Austria, y éste, en señal de aprecio, en agosto requirió al conde que preparase cincuenta lanzas para su servicio, lo nombró su montero mayor e intervino para que los regidores toledanos le devolvieran el alguacilazgo mayor de la urbe ${ }^{16}$. El marqués de Villena, por su parte, llevaba en tratos con el archiduque desde 1502, desde que había sido jurado heredero del trono de Castilla en las Cortes de Toledo. Pensaba el marqués que con el apoyo de Felipe no le resultaría complicado recuperar la influencia y el patrimonio con que contaba antes del reinado de Isabel la Católica. Ya el 5 de julio de 1504, ante el crítico estado de salud de la reina, el marqués consiguió una dispensa papal que le absolvía de juramento de lealtad que había hecho a la soberana en 1480 , lo que le permitiría recuperar sus antiguas posesiones. Unos meses más tarde, a comienzos de 1505, el marqués de Villena y el duque de Nájera se posicionaron como los grandes hombres de Felipe el Hermoso en Castilla ${ }^{17}$.

\section{LA VIOLENCIA Y LOS PROLEGÓMENOS DE LA REBELIÓN}

En un acto de coraje político, ninguneando al rey Católico, en 1505 el archiduque de Austria ordenó al marqués de Villena y al conde de Fuensalida que se encargasen de instaurar en Toledo a un nuevo corregidor. Se trataba de un plan arriesgado, de un desafío en toda regla a las autoridades públicas que actuaban en la urbe desde tiempos de la reina Isabel ${ }^{18}$. Y pese a ello los felipinos aceptaron la misión, y con el fin de desmantelar el orden público -para que Castilla fuera acusado de ineficacia- perpetraron una serie de ruydos, $e$ escándalos e muertes que pusieron a la población al borde del colapso. Algu-

15 Habían sido los Silva quienes el 16 de enero de 1475 levantaron el pendón por Isabel la Católica en el alcázar de Toledo: AGS, Contaduría del Sueldo, leg. 5, doc. 3.

16 AHN, Nobleza, Frías, catálogo 14, adición $3^{\text {a }}$.

17 FRANCO SILVA, A., Entre la derrota y la esperanza. Don Diego López Pacheco..., pp. 60 y ss.

18 En 1505 Pedro de Castilla llevaba trabajando como corregidor de Toledo catorce años. Había sido nombrado corregidor de la ciudad el 11 de febrero de 1491: AGS, RGS, 11 de febrero de 1491, fol. 23. 
nas personas fueron asesinadas en la calle o por la noche por desconocidos sin pudor que actuaban con crueldad, a la vista de todo el mundo, creando el pánico entre quienes presenciaban sus agresiones ${ }^{19}$. Especialmente hubo cuatro crímenes de una enorme repercusión, que se producirían a mediados de 1505 y durante 1506. El primero ocurrió en la primavera de 1505. Un grupo armado al servicio de caballeros cuyos nombres no se señalan intentó desafiar a la justicia en todo momento. Pasó delante de la casa del corregidor con mucho alboroto, humilló a unas prostitutas en plena calle para que los vecinos asistieran su vejación, se opuso a quienes querían impedir su jactancia y reincidió en su delito, atreviéndose a atacar a un alguacil. Todo sucedió de la siguiente manera ${ }^{20}$ :

...el miércoles que agora pasó, que se contaron syete días d'este presente mes de mayo, estando don Pedro de Castilla, mi corregidor de la noble çibdad de Toledo [de la reina Juana], e su alcalde e alguasil mayor en las casas del dicho don Pedro, en su presençia, con mucho alboroto y escándalo pasaron diez e nueve o veynte onbres armados con lanças y espadas e otras armas, e uno con una vallesta. E diz que fueron a la mançebía de la dicha çibdad e entraron en ella. E que por fuerça sacaron arrastrando çiertas mugeres del partydo ${ }^{21}$, y les tomaron e robaron todo lo que tenían. Y se salieron por un postigo del arrabal d'esa çibdad que sale al río. E que'l dicho corregidor enbió tras ellos çierta gente, e que quando llegaron ya los dichos onbres feran salidos por el dicho postygo. Y fueron tras ellos, mandando a algunos vesinos del dicho arrabal que tomasen sus armas e fuesen con ellos en seguimiento de los dichos malhechores, los quales diz que se entraron en una fermita de Sant Lázaro. E que luego llegaron los dichos alcaldes e alguasiles, e que los dichos malfechores començaron a decir " $F$ Fuera, fuera!", y çerraron las puertas de la dicha fermita, e a ello fueron conosçidos algunos d'ella.

E diz que luego, esa noche, los dichos malfechores se salieron de la dicha fermita e se fueron a algunas casas de cavalleros de la dicha çibdad, donde les tenían puestas las mesas e aparejado de çenar. E diz que non contentos d'esto, otro día syguiente algunos de los dichos malfechores tornaron a la dicha mançebía e quisyeron faser otro tanto como el día pasado, salvo porque el alcaide de la dicha mançebía con algunos onbres gelo resystieron. E que sobre ello ovo ruydo, al qual diz que vino un alguasil del dicho mi corregidor con çiertos onbres, e que los dichos malfechores le quisyeron acuchillar. E que fecho esto se metyeron en la yglesia de Sant Ysidro, desde donde diz que desýan muchas ynjurias y amenazas contra las dichas mis justicias.

19 Juan de Cepeda, por ejemplo, vecino de Toledo y morador en Torrijos, había tenido un enfrentamiento con Miguel Sánchez, y éste, un hijo suyo y dos criados salieron a le matar, e que de fecho lo posieran en obra, salvo por çiertas personas que salieron e no les dieron lugar a ello: AGS, RGS, 1506-VIII, Valladolid, 26 de agosto de 1506.

20 AGS, RGS, 1505-V, Segovia, 15 de mayo de 1505.

21 En la documentación de Toledo a las prostitutas se les denomina mugeres del partydo, mugeres públicas, mancebas, mugeres enamoradas, etc. 
El segundo acontecimiento que quebró profundamente el orden público ocurrió en junio de 1505, estando el marqués de Villena en Toledo ${ }^{22}$ :

...un sábado en la noche, que se contaron catorze días del mes de junio, a las diez oras de la noche, Juan de Porras e [blanco] de Vallejos, alguasiles d'esa dicha çibdad, fueron con mano armada, con más de treynta o quarenta onbres, a las casas de su morada e canbio de Juan de Toledo, canbiador, e con mucho alboroto dixeron contra el dicho Juan de Toledo e sus fijos "iMueran, mueran los judios!", e otras muchas palabras feas e ynjuriosas. E davan golpes con las armas a las puertas de las casas del dicho Juan de Toledo [...]

Manuel Sánchez, desde una ventana de unas casas donde él mora, que son junto con las del dicho Juan de Toledo, les dixo que por qué fasían aquello, que se fuesen con Dios, si non que les tirava una piedra. E que viendo que todavía así estavan en su mal propósito, les arrojó un pedaço de madero, e dio çerca d'ellos, porque se apartasen. E que los dichos alguasiles dexaron las puertas del dicho Juan de Toledo e fueron a las suyas, e començaron con mucho alboroto a dar golpes en ellas con las lanças e espadas, e fasiendo e diziendo otras muchas cosas feas en menospreçio de mi justiçia, con mucho escándalo e alboroto.

En el segundo semestre de 1505 la violencia aumentó de forma palpable, y las personas cercanas a Pedro de Castilla serían quienes más la sufrieran. El 31 de julio de ese año, jueves, un tal Villegas Boticario, onbre de poca manera, dio de golpes al bachiller Juan de Cañizares, alcalde y lugarteniente del corregidor. El sábado siguiente, día 2 de agosto, dos hombres del comendador Garcilaso de la Vega y su hijo mataron a un mozo de espuelas de Pedro López de Padilla (recuérdese que Padilla era de los partidarios de rey Católico) ${ }^{23}$. Lo ocurrido dio lugar a un enfrentamiento entre los Laso de la Vega y los Padilla que obligó al archiduque de Austria a intervenir el 19 de de agosto de $1505^{24}$.

Al corregidor también le acusaron de flirtear con el crimen, de no tener intención alguna de punir ciertos abusos y de moverse según el beneficio propio. Un jurado se quejaba a finales de 1505 de que había muchas muertes por castigar. Del mismo modo, otros jurados señalaban lo siguiente en un escrito que se remitió al archiduque de Austria ${ }^{25}$ : de algúnd tienpo acá han

22 AGS, RGS, 1505-VII, Segovia, 1 de julio de 1505. Felipe escribió una carta al conde de Fuensalida desde Renan, el 29 de junio de 1505, en la que le decía que estuviese en Toledo junto al marqués de Villena y cumpliera lo que le había pedido, porque el conde le había expresado su deseo de ir a la corte: Crónica de Padilla, tomo VIII, Madrid, 1846, p. 309. El marqués solía estar en Toledo y en sus alrededores con mucha frecuencia, ocupándose de sus negocios: AHN, Nobleza, Pacheco, caja 699, dos. 13 a 15 .

23 AMT, ACJ, "Actas capitulares (1470-1487). Cuentas, cartas, varios", caja 23, documento suelto.

24 AGS, Cámara de Castilla, Cédulas, libro 10, fol. 125 r.

25 AMT, "Este libro es de traslados...", Sección B, nº 120, fol. 309 r. 
aconteçido e aconteçen muchos crímenes y eçesos, y el corregidor que agora está en esta çibdad y sus ofiçiales no son obedesçidos nin executan la justiçia como cumple.

El 7 de agosto de 1505 en las inmediaciones de la iglesia de San Juan de la Leche unos hombres arrebataron a otros una mujer que traían presa. Luego se supo que los agresores eran criados del corregidor. El mercader Diego López, por su parte, había sido injuriado por un hijo y unos criados de Álvaro de Madrid, de modo que una noche, junto a un alguacil al que llamaban Santa Cruz y otros hombres, se marchó al campo para atacar a Álvaro, y finalmente mataron un onbre, pero el mercader no recibió castigo alguno. Un viernes por la noche, 20 de marzo de 1506, dos criados de Pedro de Castilla asesinaron a Sacedón. La muerte de Juan de Santa Cruz fue más escabrosa. El 1 de septiembre de 1506 el alguacil Villaseca fue a la casa de Santa Cruz para tratar un asunto relativo a una disputa que mantenía con el canónigo Juan López de León. El alguacil llevaba con él a Lorenzo Sánchez, criado del canónigo, y a otros criados suyos; finalmente-dice un documento- murió el dicho Juan de Santa Cruz, que cayó de un tejado e no bivió el dicho Juan de Santa Crus más de quatro oras después que cayó de los texados; los quales texados estavan tomados por los onbres que venían en nonbre del dicho Juan Lópes, canónigo. Ni siquiera se hizo una pesquisa seria sobre el asunto, si bien era público que habían asesinado a Juan de Santa Cruz arrojándole desde lo alto de su casa.

En la primera mitad de 1506 el caos era evidente. En enero se había producido el tercer alboroto grave de los cuatro a los que nos referíamos arriba $^{26}$; el peor hasta el momento. Se trataba del escándalo más fatídico que acontecía en la ciudad del Tajo desde hacía décadas, y su inductor fue Diego López Pacheco. Sucedió de esta manera, según un escrito fechado el 26 de enero de $1506^{27}$ :

...puede aver veynte días, poco más o menos, que sobre çierta quistión que fue entre Fernand Péres de Guzmán e Caravajal (sic), fijo de Andrés de Logroño, vesinos de la çibdad de Toledo, el dicho Fernand Péres dis que fue con syete u ocho onbres armados de diversas armas ofensivas e defensivas a casa del dicho Andrés de Logroño a buscar al dicho Carvajal, su hijo, e diziendo "iMuera, muera el traydor!". E dis que echaron mano a las espadas, e que el dicho Carvagal fue huyendo por los tejados. E que otros que estavan en la dicha casa se armaron, e fueron feridos de amas partes. E que un criado de Vasco de Guzmán que yva con el dicho Fernand Péres diz que fue muerto en el dicho ruydo. E que el dicho Fernand Péres e los que con él estavan se acogeron (sic) a la yglesia de Santo Tomé de la dicha çibdad. E que don Pedro de Castilla, nuestro corregidor de la

26 AGS, Cámara de Castilla, Personas, leg. 13, s.f., Herrera, Pedro de.

27 AGS, RGS, 1506-I, Palencia, 26 de enero de 1506. 
dicha çibdad, enbió al alcalde mayor e al alguazil mayor d'ella a la dicha yglesia a fazer pequisa sobre ello e dar horden en cómo el dicho ruydo çesase. E que los que estavan en la dicha yglesia, pensando que los querían llevar e sacar de la yglesia presos, echaron mano a las espadas contra el dicho alcalde e alguazil. E que en esto salió çierta gente armada de la casa del marqués de Villena a favor de los que estavan en la dicha yglesia, e fisieron retraer a los dichos alcalde mayor e alguasyl mayor, de que la dicha çibdad se alborotó, e se armó mucha gente en el alcáçar con don Pedro de Silva, alcaide d'ella, e con otras personas en otras partes de la dicha çibdad, e obo otras cosas de alboroto en ella...

El marqués ordenó a su gente que socorriera a Francisco de Guzmán y a los suyos, entre quienes había hombres que trabajaban para los enemigos del corregidor, que no tenían reparos a la hora de arremeter contra la justicia urbana y que ponían en tela de juicio la legitimidad de los jueces para perseguir sus delitos, mientras que, al contrario, imponían la ley del más fuerte en su sentido literal. No en vano, la resolución del suceso se confió al licenciado Arenillas, y apenas pudo trabajar debido a las presiones del marqués de Villena, que lo acusaba de no ser justo, de no tomar los testimonios como era debido ${ }^{28}$ y de ser el responsable de la muerte de algunos de sus criados, quienes tras ser detenidos habían muerto en la cárcel en circunstancias muy extrañas $^{29}$.

\section{EL ASESINATO DE TERRÍN Y EL INICIO DEL ALZAMIENTO}

La impotencia del corregidor para garantizar el orden público y el miedo que causaban los crímenes de los poderosos harían que a la altura de la primavera de 1506 muchos pensaran que tenía que ocurrir algo grave. El ambiente de violencia que se respiraba tenía que terminar mal; y los pronósticos se cumplieron. El 5 de agosto un dirigente público fue asesinado por los hombres del marqués de Villena. Su asesinato, más allá de lo truculento del mismo, podría considerarse el primer acto de la rebelión que definitivamente iniciarían el marqués y el conde de Fuensalida contra los cómplices del rey.

A principios del verano de 1506 los gobernantes de la urbe sabían que el archiduque de Austria iba a nombrar a un nuevo corregidor para su ciudad de forma inminente. Entre los que se oponían con más tenacidad a ello y a todos los actos del marqués de Villena se encontraba el jurado Diego Te-

28 AGS, RGS, 1506-III, Valladolid, 20 de marzo de 1506.

29 AGS, RGS, 1506-IV, Valladolid, 4 de abril de 1506. La comisión de licenciado Arenillas se prorrogó varias veces: AGS, RGS, 1506-IV, Valladolid, 26 de abril de 1506; AGS, C.C. Cédulas, libro 12, fol. $2 \mathrm{r}$ 
rrín ${ }^{30}$, que terminaría convirtiéndose en un obstáculo para los enemigos de Fernando el Católico.

El 27 de junio de 1506 cinco jurados fueron a la casa del conde de Fuensalida: Alonso de Sosa, el bachiller Francisco Ortiz, Luis de Aguirre, Diego Sánchez de San Pedro y Diego Terrín ${ }^{31}$. Una vez con el conde, le advirtieron que bien sabía su señoría cómo uno de los días pasados, a causa que en esta çibdad andan muchas personas - asý cavalleros como criados suyos e otros-armados (sic) contra el vedamiento de las armas en ella fecho, porque non oviese algúnd alboroto o escándalo en esta çibdad por parte del Cabildo fue suplicado e pedido por merçed al dicho señor conde que rogase a los señores sus parientes, e mandase a sus criados e allegados, que non truxesen armas, e que andoviesen en toda paçificaçión, pues que esto era lo que cunple a serviçio del rey e de la reyna nuestros señores. El conde se había mostrado dispuesto a cumplir lo que le solicitaban, pero no lo había cumplido. Y exactamente igual había pasado con los otros caballeros de la urbe. Ninguno había querido cumplir lo que se les pidió, y las dramáticas consecuencias eran evidentes: andavan muchos onbres armados de diversas armas, et, aún de más de los cavalleros e sus criados, andavan armados muchos ofiçiales e otras personas del pueblo. E aunque en el efecto se ha cunplido la yntinçión e deseo de los dichos jurados, que era que no oviese escándalo nin alborotos algunos, porque a Dios graçias fasta agora non los ha avido, pero que non se avía cunplydo lo que por su parte fue requerido [...] andando la gente tan suelta y armada se podría seguir algúnd escándalo e alboroto en esta çibdad, de que sus altesas serían deservidos ${ }^{32}$. En consecuencia, los jurados pidieron al conde que aya por bien de se juntar con el señor conde de Çifuentes [...] para que amos a dos, como personas de estado y tan emparentados, [...] pongan remedio e provean para la paçificaçión e buen estado d'esta çibdad, porque lo mismo vernían de requerir al dicho señor conde de Çifuentes, el qual avía respondido que estava presto a se juntar con el dicho señor conde de Fuensalida para lo que dicho $\mathrm{es}^{33}$.

Ante esta solicitud el conde de Fuensalida respondió a los jurados que ya había pedido a los suyos que non truxesen armas, e que sy las han traýdo

30 Un manuscrito de 1547 titulado Noticia de algunas casas de los señores grandes de España, su origen, enlaces, sucesiones, adquisiciones de estados y hechos principales de sus vidas, nos describe a Diego Terrín de la siguiente forma: "viejo verde y casquivano, de blanca barba, pero de rubia cabellera (así se llamaban entonces las pelucas), de no buena disposición, aunque de grande osadía. Llamábase Diego Terrín": Aureliano FERNÁNDEZ-GUERRA, "Antiguallas de Cadalso de los Vidrios, Guisando y Escalona", en Semanario pintoresco español, 38, Madrid 18 de septiembre, p. 299.

31 AMT, "Este libro es de traslados...", Sección B, nº 120, fol. 311 r-v.

32 Ibidem, fol. $311 \mathrm{v}$.

33 Ibidem, fols. $311 \mathrm{v}-312 \mathrm{r}$. 
después acá a seydo y es para serviçio del rey nuestro Señor, e para el sosyego e paçificaçión d'esta çibdad. Y ésta es su yntençión e voluntad de todos ellos. E asý paresçerá por la obra, syendo nesçesario. E sy sus criados e allegados traen armas fue porque vieron que otros cavalleros d'esta çibdad y sus criados andavan armados, e porque él vino a esta çibdad por mandado de sus altesas a procurar de la paçificar e tener en sosyego en su servicio; y para demostrarlo enseñó a todos los presentes una misiva de Felipe en la que se le ordenaba que mantuviera la paz en su urbe. Inmediatamente los jurados pusieron la misiva sobre sus cabezas en señal de sumisión y se manifestaron dispuestos a cumplirla, aunque es seguro que al marcharse de la casa del conde se sentirían impotentes. Sus deseos de mantener la paz chocaban con las posturas de hombres poderosos que exigían un cambio político, y lo peor era que, al parecer, dicho cambio iba a producirse mediante las armas. Y ellos, un grupo de jurados que se oponían a la violencia ${ }^{34}$, estaban posicionándose en el punto de mira de los que pretendían situar a Toledo bajo un corregidor felipino. Aun así, tal vez uno de los jurados que en junio de 1506 pidió al conde de Fuensalida que mantuviera la paz, Diego Terrín, no imaginaba entonces ni que él era el blanco de muchos odios ni que por esta causa iba a estar muerto unos días más tarde ${ }^{35}$.

El 4 de julio se supo que un caballero había arrebatado un preso a un alguacil y a otro le había quebrado su vara de justicia. Quienes estaban en la obligación de ayudar a los alguaciles les desfavorecían, y por si fuera poco algunos hombres desterrados por los alcaldes, o que se habían ido de la urbe huyendo tras cometer un crimen, volvían sin temor aprovechando la crisis que ahogaba a la justicia y el socorro que les ofrecían los caballeros; un socorro inicuo, a cambio del cual los malhechores debían perpetrar todos los actos contra el orden público que les solicitara su señor. Según uno de los jurados, Diego de Rojas, los alguaciles estaban despavoridos ante lo que veían y no osaban confiscar las armas a la gente de los caballeros, de modo que si no había más peleas y escándalos era por fortuna. Sirva un ejemplo. El 5 de julio 17 hombres armados fueron a una vivienda de las Cuatro Calles

34 Sólo un grupo de jurados, pues otros, pertenecientes a los Silva o a los Ayala, no hacían ascos a la violencia.

35 En el siglo XVI se decía que la causa de la muerte de Terrín fue ésta: "Como hallase una tarde sin testigos a Doña Juana [la marquesa de Villena] solazándose en sus jardines, tuvo atrevimiento para decirle palabras ni honestas ni decentes, que la hicieron retraer a una habitación próxima, y en su alboroto gritar a los criados que matasen aquel loco. Púsolo por obra con villana alevosía el mayordomo Vasco de Sayavedra a la mañana siguiente, sacando engañado de su casa a Terrín, y dándole muerte a palos con ayuda de otros tres mozos delante del hospital de San Pedro": Aureliano FERNÁNDEZ-GUERRA, "Antiguallas...", p. 229. 
y hubo un alboroto entre los agresores y los parientes del agredido del que salieron mal paradas dos personas ${ }^{36}$.

En esta situación, en julio de 1506, el archiduque de Austria otorgó el corregimiento de Toledo a Fernando de Andrada, conde de Caserta, pero se produjeron tales discrepancias por la aptitud de la persona elegida que el archiduque tuvo que dar marcha atrás, y el 31 de agosto concedió el oficio al doctor Rodrigo Maldonado de Talavera ${ }^{37}$. Por entonces Terrín ya estaba muerto. El 5 de agosto de 1506 fue víctima de una lucha de poder imparable. Su muerte vino a colmar el vaso de la ominosa situación que se vivía ${ }^{38}$. Esto fue lo ocurrido ${ }^{39}$ :

...estando el jurado Diego Terrín [...] muy flaco e quartanario en la yglesia de Santiuste oyendo misa, estovieron aguardándole seys onbres de pie de la casa del marqués de Villena, e con palabras de engaño le sacaron de la dicha yglesia e se vinieron con él fasta çerca de la yglesia mayor, cabe donde mora Pedro de Fuentes, teniente de fiscal, e Unbruxuelas, carpintero. E allí, todos, seys juntos, le tomaron en medio e con quatro palos de vara de lança le dieron tantos palos en la cabeça, e braços e cuerpo, e en el suelo caydo le dieron más, que nunca más fabló. E el mismo día pasó d'esta presente vida. E los que le mataron se fueron públicamente por esta çibdad, e dizen que se metieron en las casas del marqués...

En la demanda puesta por los jurados ante el Consejo Real se afirmaría que los asesinos habían salido de las casas del marqués de Villena: seys onbres de pie o más [...] le dieron tantos palos que dieron con él en el suelo, de que diz que murió luego naturalmente, syn que pudiese fablar ni declarar por qué lo mataron. El día del crimen, en una reunión urgente en el ayuntamiento, los jurados clamaban contra lo ocurrido, calificándolo de mal fecho, trayçión y avergonçada muerte ${ }^{40}$. Llamaron al bachiller de Bonilla, lugarteniente del alcalde mayor, y le pidieron que hiciese una pesquisa; y diputaron a Juan Pérez de Vallejo y a Gonzalo Pérez de Rojas para acompañasen en su investigación a Bonilla. Luego fueron a casa del corregidor a decirle lo que iban a hacer, y mandaron a la corte a un correo para explicar lo ocurrido.

Una vez se supo en la corte lo que había pasado se comisionó al doctor Antonio Cornejo para investigar el crimen; un crimen que claramente era un

36 AMT, "Este libro es de traslados...", Sección B, nº. 120, fol. 360 r-v.

37 El 4 de septiembre de 1506 se ordenaba a los contadores mayores que pagaran al doctor Rodrigo Maldonado el salario que pagaban a Pedro de Castilla: AGS, Cámara de Castilla, Cédulas, libro 12, fol. 104 r.

38 Diego Terrín vivía en la parroquia de San Miguel: AMT, "Este libro es de traslados...", Sección B, ${ }^{\circ}$. 120, fol. $261 \mathrm{r}$.

39 Ibidem, fols. 226 r-229 r y 356 r; IZQUIERDO BENITO, R., Un espacio desordenado: Toledo a fines de la Edad Media, Toledo, 1996, doc. 95, pp. 240-241.

40 AMT, "Este libro es de traslados...", Sección B, nº 120, fol. 248 r-v. 
atentado político ${ }^{41}$. Pero Cornejo tuvo tres problemas. Por una parte, pronto se supo que detrás de la muerte de Terrín estaba la marquesa de Villena ${ }^{42}$, la mujer más poderosa de Toledo por entonces. Ajusticiarla sería del todo imposible. Por otra parte, los sirvientes de la marquesa, quienes cometieron el crimen, se habían amparado en los castillos de la comarca, así que también sería difícil ajusticiarlos ${ }^{43}$. Además, y puesto que los marqueses de Villena eran colaboradores del archiduque Felipe, era palmario que la desaparición de Terrín servía a la causa felipina, por lo que no faltaron todo tipo de presiones para librar de sus condenas a las personas imputadas en el crimen. Sin ir más lejos el regidor Juan Ramírez de Guzmán, que se demostró que había conspirado contra Diego Terrín, obtuvo una carta de Felipe que le exoneraba del destierro al que fue condenado ${ }^{44}$. No obstante, el mayor obstáculo con que se topó Cornejo a la hora de hacer justicia fue la actitud de quienes habían intervenido en el crimen, que, envalentonados y lejos de exhibir algún tipo de remordimiento, amenazaban con matar a otros gobernantes.

Los compañeros del difunto, apremiados e atemorizados, afirmaban que de no hacerse justicia no osarían informar de nada de lo que ocurría en Toledo a la corte, pues no estaban dispuestos a morir por culpa de su trabajo. Por contra, la actitud de individuos como el conde de Fuensalida ante la muerte de Terrín fue fría y distante: se limitó a mandar a los jurados que le obedecieran si querían que imperara el orden. Y es que este era el objetivo del asesinato de Terrín: convencer a los que estaban en contra de los seguidores del archiduque Felipe de lo que les convenía, obligarlos a someterse a aquellos que, en teoría, estaban listos para imponer la paz. Los crímenes evidenciaban que Pedro de Castilla y el rey eran incapaces mantener el orden, mientras que, por contra, la muerte de Diego Terrín dejaba claro que el marqués y los suyos eran capaces de todo para controlar Toledo. Aun así, surgió un imprevisto. El 25 de septiembre de 1506 el archiduque Felipe fallecía repentinamente, en extrañas circunstancias.

\section{LA ESTRATEGIA FORZADA DEL CONDE DE FUENSALIDA}

Tras la muerte del archiduque el control de Castilla quedó bajo la tutela del arzobispo Francisco Jiménez de Cisneros, estableciéndose un período de 90 días para decidir el futuro de la Corona. Inmediatamente se convocaron unas Cortes, en las que se puso de manifiesto la tensión política en que se

41 AGS, RGS, 1506-VIII, Tudela, 13 de agosto de 1506.

42 AGS, Secretaría de Estado, leg. 1 (2), fol. 202.

43 AGS, RGS, 1506-VIII, Tudela de Duero, 25 de agosto de 1506.

44 AGS, RGS, 1506-XI, 8 de noviembre de 1506. 
hallaban muchos territorios, y en especial las ciudades ${ }^{45}$, entre otros motivos porque la muerte de Felipe venía a trastocar muchas expectativas, sobre todo las de hombres como el duque de Nájera, el señor de Belmonte, el conde de Fuensalida y el marqués de Villena.

Durante unos días los felipinos quedaron conmocionados por la muerte del archiduque. No se esperaban semejante acontecimiento, y les pilló sin un plan alternativo para hacerse con el control del reino. La defunción de Felipe hizo que se disolviese el partido de nobles que le apoyaba, y se vinieron abajo las ilusiones de quienes pretendían recuperar el terreno perdido en época de los Reyes Católicos. Hubo nobles, sin embargo, que reaccionaron rápidamente. Para los antiguos enemigos de la reina Isabel estaba muy claro que, más allá del archiduque, había que impedir que el rey Fernando recuperase el control de Castilla, había que seguir con el plan establecido hasta donde fuera posible, pues realmente el archiduque era una excusa. Muchos le habían favorecido sólo para recuperar poder; una meta por la que había que seguir luchando aunque ya no estuviese el archiduque. Todo debía seguir igual ${ }^{46}$.

El conde de Fuensalida se sumó a la postura de quienes se mostraban recalcitrantes en sus ideas políticas, y para demostrarlo envió un ultimátum a los jurados advirtiéndoles de sus intenciones de hacerse con el control de la ciudad ${ }^{47}$. Según el conde, en 1505 el archiduque le había devuelto su alguacilazgo mayor ${ }^{48}$, pero Pedro de Castilla se negaba a ceder el oficio, lo que le legitimaba para recuperarlo a la fuerza.

Los jurados, temiéndose lo peor, enviaron un escrito a la reina Juana en el que advertían sobre la situación límite de Toledo ${ }^{49}$. No estaban seguros ni de hasta dónde estaba dispuesto a llegar el conde de Fuensalida ni de cuál podía ser la reacción de sus rivales, pero los Ayala no exhibían ningún comedimiento en su actitud.

En 19 de octubre de 1506, empero, el conde de Fuensalida decidió pasar de las palabras a la acción ${ }^{50}$. Cuando el corregidor estaba en el ayuntamiento con otros gobernantes algunas personas, vesinos d'esa dicha çibdad, fueron con armas e en son de alboroto e escándalo a la puerta del dicho ayuntamiento,

45 FERNÁNDEZ ALBADALEJO, P., "Los Austrias mayores...", p. 31.

46 Real Academia de la Historia, Colección Salazar y Castro, sig. 9/235, fol. 127 r-v.

47 AHN, Nobleza, Frías, leg. 847, doc. 18, fols. 1 r-2 r.

48 AHN, Nobleza, Frías, caja 847, doc. 17.

49 AMT, "Este libro es de traslados...", Sección B, no. 120, fol. 309 r.

50 AGS, RGS, 1506-XI, Burgos, 21 de noviembre de 1506; AMT, ACJ, Documentos Originales, $\mathrm{n}^{\circ}$. 78; MARTÍN GAMERO, A., Historia de la ciudad de Toledo, sus claros varones, sus monumentos, 2 vols, Toledo, 1862, (Edic. facsímil, Toledo, 1979), vol. 2, pp. 924-936. 
e otros se pusyeron en la casa del arçobispo, e otros se pusyeron en la yglesia mayor d'esa dicha çibdad, a las puertas d'ella, junto con las cadenas, e otros se pusyeron por las calles e cantones, junto con las dichas casas del ayuntamiento, por escandalizar e rebolver esa çibdad, e por la poner en discordia.

Para frenar esta situación, en nombre de la reina Juana se requirió a Castilla que hiciese justicia contra los alborotadores, y unos días después, el 30 de octubre, el Ayuntamiento decretó que nadie trajese armas por la ciudad, aunque tuviera licencia para hacerlo. Quien lo hiciese, además de perder las armas, sería desterrado por un año de la urbe. Se buscaba calmar la tensión a toda costa. Pero fue inútil. Muchos se habían armado y la revuelta resultaba inminente. Por eso, aparte de pedir a la población que estuviera en mucha paz e sosiego, se ordenó a los alguaciles que rondasen por las calles día y noche, y que prendieran y castigaran a todos los malfechores ${ }^{51}$; y el jurado Diego Fernández de Madrid, que apoyaba esas medidas, solicitó a sus compañeros que estuviesen unidos, conformes e unánimes frente a la actuación de los caballeros ${ }^{52}$. Lo malo era que incluso en el Cabildo había diferencias. Juan Ramírez de Sosa, por ejemplo, defendía que para evitar escándalos lo mejor era que todos se juntaran con los regidores para pactar una solución con los partidarios del archiduque ${ }^{53}$. Diego de Rojas, por su parte, decía que lo correcto era obedecer al corregidor y sus hombres ${ }^{54}$, por mucho que los del marqués dijesen que la justicia estaba corrupta y que la obediencia al corregidor era alegal -pues para ellos Pedro de Castilla ocupaba su oficio clandestinamente por orden del rey Fernando-. El problema era que pasaban los días y ningún hombre del archiduque venía a la urbe para rescatar el corregimiento, lo que, por otro lado, no impidió al conde de Fuensalida proceder con contundencia.

El 25 de noviembre el conde, por enésima vez, exigió a los jurados su apoyo, y como siempre le respondieron que estaban listos para hacer todo lo necesario por la paçificación de la ciudad, pero que no veían justa la disposición del archiduque por la que él y Diego López Pacheco debían dirigir las labores pacificadoras ${ }^{55}$. Ante esta respuesta, consciente de que sólo podía confiar en su bando, el jueves 26 de noviembre el conde se alzó en armas ${ }^{56}$.

51 AGS, RGS, 1506-X, Burgos, 30 de octubre de 1506.

52 AMT, "Este libro es de traslados...", Sección B, nº. 120, fol. 321 r.

53 Ibidem, fol. $359 \mathrm{r}$.

54 Ibidem, fol. $360 \mathrm{r}-\mathrm{v}$.

55 Ibidem, fols. 329 r y 344 r-345 v; AGS, Cámara de Castilla, Pueblos, leg. 20, fols. 239 y 240.

56 Ibidem, fols. 228 r, 324 v y 344 r-345 v; AGS, Cámara de Castilla, Pueblos, leg. 20, fols. 239-240. 
Rodeado de una multitud de sirvientes y secuaces políticos, se puso a la cabeza de una muchedumbre de hombres armados y salió a las calles de la ciudad exhibiendo unas varas de justicia. Las varas eran palos "del grueso de un dedo y largas de la estatura de un hombre" que servían para simbolizar la posesión del imperio para hacer cumplir la ley. El conde quería mostrar pública y notoriamente su desacato al corregidor ${ }^{57}$.

Viéndolo algunos jurados, entonces reunidos en el ayuntamiento, conscientes de lo que podía ocurrir de contestarse a la provocación del conde con violencia, acordaron que dos de ellos fueran a la casa de Pedro de Castilla para pedirle que ni él ni los suyos saliesen a la calle, pues de lo contrario el perdimiento de la ciudad sería ineludible. En principio el corregidor, furioso, se opuso a la solicitud de los jurados y pidió a Fernando de Segovia y a los suyos que se armasen y se unieran a é ${ }^{58}$, pero luego optó por aceptar lo que se le pedía. Otros jurados fueron en busca del conde y su gente, y los hallaron en la calle del Pozo nuevo, donde les pidieron que se volvieran a sus casas y no provocasen alborotos e ruidos. Aun así, el conde, rodeado de su clientela armada, despreció toda solicitud de apaciguamiento y se dirigió a la plaza de Zocodover pregonando que no tenía a Pedro de Castilla por corregidor. Una vez en la plaza, en medio de una multitud expectante, uno de los criados del líder de los Ayala dio dos pregones con gravísimas penas contra los que cometiesen un delito. El conde y los suyos se autoproclamaban los amos de Toledo ${ }^{59}$.

Tras los pregones la comitiva armada volvió a la catedral por las calles del barrio del rey, las carnicerías y las pescaderías. Según un testimonio de la época la gente menuda andaba huyendo con gran temor de perder sus vidas y bienes. Nadie sabía cuál era la intención última del enorme séquito armado reunido por el conde. Algunos afirmaban que iban asesinar al corregidor y a sus adeptos, entre quienes se hallaba un buen número de hombres próximos a los Silva, de modo que podía comenzar una auténtica guerra civil. Pero no aconteció de este modo. Muy cerca de la catedral la comitiva armada se disolvió gracias a la intermediación de Diego de Cárdenas, comendador mayor de León y adelantado de Granada, y aunque el viernes 27 se volvieron a reunir personas armadas tanto del bando del conde como del corregidor, ese día se

57 MALDONADO, J., La revolución comunera. El movimiento de España, o sea, historia de la revolución conocida con el nombre de las Comunidades de Castilla, FERNÁNDEZ VARGAS, V. (Edit.), Madrid, 1975, p. 84.; BECEIRO PITA, I., "La imagen del poder feudal en las tomas de posesión bajomedievales castellanas", en Studia Historica. Historia Medieval, 2, Salamanca 1984, pp. 157-162, en concreto p. 160.

58 AMT, "Este libro es de traslados...", Sección B, nº 120, fol. 314 r.

59 AHN, Nobleza, Frías, leg. 18, fol. 138. 
concertó una tregua hasta el lunes 30, y Cárdenas confiscó sus varas a los alguaciles de Castilla y a los que había puesto el conde ${ }^{60}$.

\section{LA IMPOSICION DE LA PAZ Y SUS DEBILIDADES}

En medio del conflicto los jurados desarrollaban sus gestiones sin descanso con el fin de mantener el orden, y por suerte no parecían estar solos: contaban con el auxilio de personas como Diego de Cárdenas y algunos clérigos, que insistían en inmiscuirse en la disputa para impedir una revuelta. Mientras, el conde Cifuentes permanecía al margen ${ }^{61}$. Es seguro que no pocos de los hombres que habían acudido a las armas y permanecían con el corregidor en su vivienda eran criados de los Silva, de los Padilla, de los Ribera y de sus cómplices, aunque estos deseaban estar por ahora en un segundo plano. El archiduque había fallecido y el reino nuevamente iba a ser del rey Católico. Su opción política había triunfado, como en la década de 1470, cuando los Ayala se pusieron del lado de Juana -la "Beltraneja"- y los Silva del de Isabel. La inquietud del conde de Fuensalida era lógica. Los Silva, no obstante, sólo debían resistir hasta que Fernando se hiciese con la Corona de nuevo. Y sin embargo, entre el viernes 27 de noviembre de 1506 y el lunes 30 los habitantes de Toledo vivirían una situación trágica. Nadie sabía lo que iba a suceder cuando terminara la tregua de 48 horas que se había firmado. Ya el día 27 el corregidor había pedido a los jurados que acudieran a las armas para pelear a su favor, pero le respondieron que no lo harían, y que era mejor que él tampoco lo hiciese ${ }^{62}$. Por contra, el Cabildo de jurados realizó un informe sobre lo sucedido para que lo llevara al Consejo Real uno de sus compañeros, Tomé Sánchez ${ }^{63}$, y no un correo. Había que elegir muy bien a las personas que iban a la corte; los correos estaban comprados y las cartas se perdían por el camino ${ }^{64}$. En todo caso, Sánchez tendría que realizar una tarea imposible: en poco más de una jornada tenía que ir a la corte y traer alguna disposición para el apaciguamiento de su çibdad. Como es lógico, no se pudo dar conçierto en tan pocas horas.

60 AMT, "Este libro es de traslados...", Sección B, nº. 120, fol. 228 r.

61 ACT, Actas capitulares, libro $2^{\circ}$, desde el 19 de junio de 1506 al 29 de octubre de 1510, reunión del 31 de octubre de 1506, f. 17 v.

62 A los jurados a quienes se requirió esto eran aquellos que estaban reunidos en el Ayuntamiento de Toledo: el bachiller Diego Martínez de Ortega, Alfonso de Sosa, Diego de Rojas, Diego Sánchez de San Pedro, Diego Fernández de Madrid, el licenciado Pedro de Herrera, Francisco Fernández de Oseguera, Juan Sánchez de San Pedro, Ruy Pérez de la Fuente, Pedro Ortega, Miguel Díaz, Diego de Argame y Fernando Pérez de Aguilera.

63 AMT, "Este libro es de traslados...", Sección B, nº 120, fol. 295 r-v.

64 Ibidem, fols. 324 r-327 v. 
Los canónigos de la catedral, por su parte, se prepararon para lo peor. El mismo día 27 de noviembre en una junta establecieron lo que sigue bajo rigurosas penas ${ }^{65}$ :

... sobre los escándalos e diferençias que en esta çibdad se temen que avrá entre los cavalleros d'ella [...] unánimes se conformaron e concordaron que, por evitar el peligro que se espera, asý en las personas d'ellos [d'ellos aparece tachado] de los cavalleros, e daño de toda la çibdad e el reyno sy viniese en ronpimiento, e por lo que toca a sus conçiençias, que ellos, como ministros de la yglesia, todos, estén fechos un cuerpo e una unión para conservaçión e pacificaçión de las diferençias e debates. E, lo que Dios no quiera, viniendo en ronpimiento que ellos, todos, asý los reverendos señores deán e cabildo como los raçioneros e capellanes de la yglesia, como todos los otros capellanes de las capillas e benefiçiados, e otros clérigos qualesquier de la dicha çibdad de Toledo, estén en una unión syn discrepar de lo que la yglesia [la yglesia está tachado] les mandaren, e que ninguno discrepe ni vaya a casa de ningúnd grande ni otra persona, ni en su casa no acoxga gente, de manera que acueste a parte alguna -ellos ni otro por ellos suyos, ni otros por ellos enviados-, salvo que estén a lo que los señores deán e cabildo mandaren, porque su voluntad es fazer lo que son obligados para la pacificaçión de la çibdad a serviçio de Dios, nuestro Señor, e bien común que de justiçia se debe, e al serviçio de la reyna, nuestra señora [de la reyna, nuestra señora está tachado con mucha tinta, para que no se pueda leer] de sus altezas...

El sábado 28 de noviembre un procurador del conde de Fuensalida, Alfonso de Aguilar, pidió a los jurados que no obedecieran el requerimiento de ayuda hecho el viernes por Pedro de Castilla, y que se mostrasen partidarios de los Ayala ${ }^{66}$. La respuesta, negativa, fue idéntica a la dada al corregidor.

Tanto los Ayala como los seguidores del corregidor querían que los jurados se sumasen a su causa porque con su ayuda, con la ayuda de los representantes de las parroquias, no sería difícil movilizar a los vecinos. Pero los jurados no apostaban ni por unos ni por otros, así que los conspiradores decidieron llamar a sus vasallos de las aldeas de alrededor de la urbe ${ }^{67}$, y el 30 de noviembre, viendo que de amas partes venían muchas gentes de cavalleros e capitanes de la comarca d'esta çibdad e muchas gentes armadas de pie y de cavallo, e algunos entravan por el río y otros por las puertas, y otros por portillos y lugares proybidos, de que estava aparejado muy grand escándalo y perdiçion d'esta çibdad, todos los del Cabilldo d'esta Santa Yglesia y nosotros, los jurados, con ellos, requerimos al corregidor e a los cavalleros que en su favor estavan, de

65 ACT, Actas capitulares, libro $2^{\circ}$, desde el 19 de junio de 1506 al 29 de octubre de 1510, reunión del 27 de noviembre de 1506, fols. $21 \mathrm{v}-22 \mathrm{r}$.

66 AMT, "Este libro es de traslados...", Sección B, nº. 120, fol. 330 r-v; AHN, Nobleza, Frías, leg. 847, doc. 18, fol. 2 r-v.

67 AMT, "Este libro es de traslados...", Sección B, nº 120, fol. 228 r. 
parte de vuestra altesa [la reina Juana], que toviesen pas. E asimismo al dicho conde de Fuentsalida y a los cavalleros que con él estavan, otro tanto. Además se puso un entredicho sobre las iglesias de la urbe $e^{68}$, y se pregonó que no se alzaría hasta que no se desencastillasen los templos en los que se habían atrincherado decenas de hombres listos para combatir.

Había personas armadas por toda la ciudad, pero sobre todo en el centro neurálgico de las Cuatro calles. Las exhibiciones de fuerza eran tan amedrentadoras, amenazaban hasta tal punto con producir un enfrentamiento de costes inasumibles y de resultados dudosos, que las facciones enfrentadas hubieron de replantearse lo que estaba pasando y se convino no pelear por el momento. Apresuradamente se produjo una negociación, y todos concluyeron que unos jueces resolvieran si Pedro de Castilla debía ser corregidor y si el conde de Fuensalida estaba legitimado para utilizar su oficio de alguacil. Lo que los jueces sentenciaran, acordaron unos y otros, habría de cumplirse obligatoriamente.

El 1 de diciembre de 1506 los jurados escribieron a la corte para aclarar lo que sucedía. Según afirmaban, si no se había producido un rompimiento más grave en su ciudad era gracias a la colaboración entre ellos y los canónigos $^{69}$ y a la pasividad del corregidor y su gente, que no habían salido a combatir a Ayala. Esperamos en nuestro Señor-sentenciaban los jurados-que con la declaraçión que fisyeren se sosegará mucho de una parte y de otra ${ }^{70}$.

La respuesta que se dio en nombre de la reina Juana a estos sucesos fue rotunda. El 4 de diciembre se comisionó al licenciado Gonzalo de Gallegos para que resolviera la trifulca. De parte de la soberana debería ordenar al conde de Fuensalida y a los suyos que no usasen los alguacilazgos y que se sometieran al corregidor. De no hacerlo caerían en mal caso, y en consecuencia perderían sus derechos a poseer tales oficios ${ }^{71}$. Además, se autorizó a Gallegos para castigar a los malfechores que intervinieron en el motín del 27 de noviembre. Habría de perseguirlos por toda la ciudad y sus alrededores, entrando en los castillos y en otros lugares en donde estuvieran amparados. Una vez en su poder, Gallegos los tendría que castigar con la máxima dureza,

68 Ibidem, reunión del 31 de diciembre de 1506, f. 26 r.

69 El 30 de diciembre de 1506 diputaron a los arcedianos de Toledo y de Madrid, al capiscol, al capellán mayor, al contador Gonzalo Ruiz y al licenciado de Mazuecos para que fuesen sobre la paz a entender entre estos cavalleros de la dicha çibdad, e digan todo lo que conviene para la pacificaçión, e fagan e concuerden como les pareciere, espeçialmente [...] les digan que la yglesia estaba en unión para la paz: ACT, Actas capitulares, libro $2^{\circ}$, desde el 19 de junio de 1506 al 29 de octubre de 1510, reunión del 30 de diciembre de 1506, f. 26 r.

70 AHN, Nobleza, Frías, catálogo 14, nº 1.

71 AHN, Nobleza, Frías, leg. 18, doc. 138-139. 
como si hubieran realizado su delito en la propia corte, violando el sosiego que en ella debía reinar. La postura de la corte era categórica, y eso quitó mucha presión a los jurados, que el 9 de diciembre escribieron al conde de Fuensalida reprochándole lo que había ocurrido ${ }^{72}$. Un día después desde la corte se les remitió una carta pidiéndoles que ayudasen al pacificador que iba a ir a la urbe a sosegarla ${ }^{73}$.

En los primeros días de diciembre todos los omes poderosos de Toledo conocían bien la actitud de la Corona ante lo sucedido, pero aun así, el día 12 firmaron una concordia no con fines precisamente pacíficos ${ }^{74}$, y la rubricaron todos los oligarcas, hasta aquellos que hasta la fecha habían permanecido al margen. La tensión acumulada entre el 27 y el 30 de noviembre había hecho que todos se implicasen en la disputa. Pese a la indiferencia falaz de los Silva y de sus partidarios, pese a que el conflicto sólo afectaba al corregidor y al conde de Fuensalida, la actitud de este último había hecho que se regenerasen los arcaicos vínculos de solidaridad que articulaban al bando de los Silva; unos vínculos que se habían debilitado en la época de la reina Católica. Y es que aunque el corregidor no era bien visto por algunos de los cómplices del conde de Cifuentes lo apoyaron sólo para impedir el triunfo de los Ayala ${ }^{75}$. La concordia del 12 de diciembre de 1506 es una buena manifestación de ello.

Al contrario de lo que se ha escrito en alguna ocasión calificando la avenencia del mes de diciembre de 1506 como un acuerdo para mantener la $\mathrm{paz}^{76}$, realmente lo que se firmó por entonces no era un compromiso para impedir la lucha entre los caballeros sino algo totalmente opuesto: un pacto en el que se concertaba el modo en que debían batallar las facciones rivales de producirse un alboroto. En la concordia de diciembre de 1506 no se alegaba que había que sostener la paz, sino que, de no sostenerse, los enfrentamientos debían producirse empleando sólo armas defensivas como

72 AHN, Nobleza, Frías, leg. 847, doc. 18.

73 AMT, A.C.J., D.O., $\mathrm{n}^{\circ} .79$.

74 AMT, AS, caj. $1^{\circ}$, leg. $1^{\circ}, n^{\circ} .27$; B.N.M., Mss. 13.112, fols. 43 r-48 v; MARTÍN GAMERO, A., Historia de la ciudad de Toledo..., tomo 2, doc. XXVI, pp. 1.069-1.073; BENITO RUANO, E., Toledo en el siglo XV. Vida política, Madrid, CSIC, 1967, doc. 97, pp. 305-310.

75 AGS, Cámara de Castilla, Personas, leg. 6, fol. 277.

76 MARTÍN GAMERO, A., Historia de la ciudad de Toledo..., tomo 2, doc. XXVI, p. 1.069. En BENITO RUANO, E., Toledo en el siglo XV..., p. 130 se dice lo siguiente: "es el 12 de diciembre de 1506, en efecto, dos meses después de la muerte de Felipe "el Hermoso", cuando por doble iniciativa del Ayuntamiento y del Cabildo catedralicio se concertó un acuerdo entre los caballeros, escuderos e hijosdalgo en general de Toledo, según el cual ninguno participaría en desorden alguno que se promoviera en la ciudad, ni consentiría que pariente ni servidor suyo tirase tiro de flechas o pólvora...". 
espadas, escudos y puñales, y no armamento ofensivo -flechas, espingardas, cañones-. La concordia decía así:

...agora nin en ningún tiempo del mundo si en esta çibdad, lo que Dios no quiera, oviere algún alboroto, o escándalo o ruido non consentirán que ellos, nin sus parientes, ni amigos, ni criados, ni valedores, ni allegados ni otra persona alguna desta cibdad, ni de fuera della, tiren espingardas, ni ballestas, ni arcos con flechas, ni tiro grande ni pequeño de pólvora, ni otra ninguna especie de artillería, ni lo saquen por calles, ni de dentro de casa tiren a la calle, de manera que puedan ofender a nadie con ello, así en casas como en calles, como en otra parte ninguna, ni se ponga, ni pueda poner, fuego de ninguna especie ni calidad que sea en ninguna parte de la dicha cibdad ${ }^{77}$, ni se pueda interpretar ni dar otro entendimiento a esta escritura salvo que en ninguna vía ni forma no se puedan tirar los dichos tiros, ni sacar ni tomar para los dichos ruidos, ni alborotos, ni escándalos ni ayuntamientos de gentes, ni se poner ni echar fuego en manera alguna...

En ningún momento los poderosos se comprometerían a mantener el orden. Sólo debían jurar que de producirse un escándalo las armas ofensivas no serían usadas, so pena de perder la vida y los bienes. Sólo por traerlas en público se condenaría a quien las trajese a la pérdida de uno de los miembros del cuerpo -las orejas, una mano-. Ahora bien: ¿por qué se pactó que los enfrentamientos se produjesen de esta manera? En las propias líneas del compromiso se respondía a tal cuestión:

...aunque en esta cibdad ha habido muchos movimientos y alteraciones nunca Nuestro Señor permitió que en ellos muriese alguna persona principal, de cuya causa oviera habido entre los caballeros desta cibdad enemistades perpetuas, según vemos que ha acontecido y dura hoy en muchas cibdades destos reinos. Y pues Dios lo hizo hasta aquí maravillosamente, y porque esto dure para siempre, y porque los buenos caballeros y escuderos y los buenos sean conocidos por tales y no sean muertos por los hombres de baja suerte malamente...

Como puede observarse, a la altura de 1506 había un doble temor entre los caballeros: un temor a que surgieran entre sus filas odios perpetuos que parecían haber desaparecido tras las disputas de épocas pasadas, y un temor a que por culpa de los enfrentamientos provocados a raíz de ese odio algún caballero pudiese morir de forma vergonzante, a manos de personas del común. Indudablemente, al leer la concordia muchos se acordarían del

77 Aquí se estaba haciendo una referencia directa al incendio que se produjo en la revuelta de 1467 , en la que los cristianos viejos prendieron fuego a las casas de unos judeoconversos, el fuego se extendió y destruyó casi todo el parroquia de Santa María Madgalena, lo que según algunos testigos de la época destruyó más de 1.600 casas, en las que vivían 4.000 personas. Sobre los pormenores de este conflicto véase: LÓPEZ GÓMEZ, Ó., Los Reyes Católicos..., pp. 54-71. 
asesinato de Diego Terrín y de las agresiones que estaban sufriendo los alguaciles. No obstante, lo más llamativo era el carácter profético de algunas de las ideas formuladas en el pacto de diciembre de 1506. Aunque la revuelta de las Comunidades se produciría catorce años después, en 1520, en 1506 en la ciudad de Tajo los caballeros ya advertían del peligro que podía acarrear la implicación del común en un movimiento armado en el que los poderosos fuesen las víctimas; algo que sucedería precisamente durante la rebelión de las Comunidades, en la que no pocos caballeros acabaron convirtiéndose en víctimas de la furia de los menores. De manera que al final se cumplirían los malos augurios anunciados en la concordia de 1506. Ya por entonces estaba precisándose la ideología anticomunera que luego iban a manifestar muchos miembros de la caballería.

Para acogerse a lo pactado el 12 de diciembre cada caballero tuvo que jurar que lo iba a cumplir ante notario y en las manos de un sacerdote (so pena de excomunión) antes de hacer pleito-homenaje en manos de otro caballero (so pena de caer en mal caso). Se trataba de una forma de actuar propia de los siglos XIV y XV: un procedimiento típico de la resolución de las disputas de manera infrajudicial, al margen de la justicia ${ }^{78}$. Este tipo de actos normalmente solía celebrarse en un espacio y un tiempo sagrados (un domingo o un Viernes Santo, en una iglesia, un convento o un monasterio). La figura del sacerdote en tanto que delegado de Dios era esencial. No obstante, en la concordia de 1506 no se procedió exactamente de este modo. Lejos de reunirse los caballeros de las distintas facciones en un lugar específico para jurar la concordia, ésta fue jurada por cada parte en un lugar distinto, sin reunirse: los Ayala por un lado, y los Silva y el corregidor por otro. Se trata de un dato que viene corroborar lo referido arriba. Lo acordado en diciembre de 1506 no buscaba mantener la paz, sino definir una forma de enfrentarse en caso de que la violencia fuera irremisible.

78 El análisis de las prácticas infra-judiciales, es decir, al margen de la justicia oficial, se ha convertido en uno de los temas de estudio más importantes de los últimos años al analizar todo lo relativo a la Edad Media. Véase, por ejemplo: SOMAN, A., "L'infrajustice à Paris d'après les archives notariales", Histoire, économie, société, 1, París 1982, pp. 369-372; GARNOT, B. (Edit.), L'infrajudiciaire du Moyen Age à l'epoque contemporaine, Dijon, 1996; ZORZI, A., "Conflicts et pratiques infrajudiciaires dans les formations politiques italiennes du XIII ${ }^{e}$ au $\mathrm{XV}^{\mathrm{e}}$ siècle", en Ibidem, pp. 19-36; ROUSSEAUX, X., "L'assistance dans la résolution des conflits aux PaysBas méridionaux (fin du Moyen Age et Temps Modernes)", en L'assistance dans la résoluition de conflits. Recuils de la Société Jean Bodin, Bruselas, 1997, pp. 129-162; OFFENSTADT, N., "Interaction et régulation des conflits. Les gestes d l'arbitrage et de la conciliation au Moyen Age (XIII-XV siècles)", en GAUVARD, C. y JACOB, R. (Edits.), Les rites de la justice. Gestes et rituels judiciaires au Moyen Age occidental, París, 2000, pp. 201-228. 
Establecidos los cánones de la concordia, el 12 de diciembre se reunieron con el conde de Fuensalida, en su casa, Enrique Manrique, Pedro de Ayala, Vasco de Guzmán, Juan Niño, Vasco Suárez, Perafán de Ribera, Luis de Guzmán, Fernando Chacón, Pedro de Acuña, Vasco de Contreras, Martín de Rojas, Pedro Vélez, Antonio Álvarez, Juan Carrillo y Vasco Ramírez de Guzmán. Tras haber hecho juramento ante notario y en manos de Juan de Quintanapalla, arcediano de Cuéllar y canónigo de la catedral, hicieron pleito-homenaje en manos del regidor Juan Carrillo (otro Juan Carrillo diferente del de la lista anterior). De forma paralela el conde de Cifuentes se reunió en su casa con Pedro López de Padilla, Pedro de Silva, Per Álvarez de Ayllón, Francisco Suárez, Diego de Merlo, el regidor Juan Carrillo -que haría de mensajero entre las viviendas de los líderes de las facciones-, Fernando de Zúñiga, Fernando Pérez de Guzmán, Tello de Guzmán, Gonzalo Gaitán, el comendador Alonso de Escobar y otro Tello de Guzmán, en este caso el comendador de Calatrava. De la misma manera que en el caso de los seguidores del conde de Fuensalida, en la casa del conde de Cifuentes sus partidarios, tras hacer su juramento a Quintanapalla, hicieron pleito-homenaje en manos de Vasco Suárez ${ }^{79}$.

Por último, en la vivienda de Pedro de Castilla éste y los de su casa también juraron la concordia, y, curiosamente, hicieron pleito-homenaje en manos de Vasco Suárez, el mismo que de parte del conde de Fuensalida lo había tomado a los Silva y su gente. Y es que a pesar de las reservas de unos y de otros las posiciones estaban claras: el enfrentamiento era entre los Ayala y el corregidor, pero el corregidor contaba con colaboradores poderosos ${ }^{80}$.

El 13 de diciembre, en el claustro de la catedral, otros hombres del conde de Cifuentes juraron la concordia, también en manos de Vasco Suárez: Carlos de Guevara, Diego García de Cisneros, Juan Osorio, Juan de Guzmán, Rodrigo Niño, Fernando Díaz de Ribadeneira, Diego Pérez de Ribadeneira, Tello Palomeque y Juan de Ayala ${ }^{81}$. A lo largo de los días siguientes la concordia se pregonó por las calles y las plazas para que el pueblo la conociera, y para que de producirse un conflicto nadie acudiese con armas ofensivas. Se trataba de una declaración de intenciones que, en cualquier caso, no logró calmar los nervios que existían. De hecho, apenas una semana después, el 19 de diciembre, se empezaron a oír las primeras críticas. Los alcaides de las fortalezas, asustados frente a los rumores que seguían advirtiendo sobre una

79 MARTÍn GAMERO, A., Historia de la ciudad de Toledo..., tomo 2, doc. XXVI, pp. 1.070-1.071.

80 AMT, "Este libro es de traslados...", Sección B, n. 120, fol. 23 r.

81 MARTÍN GAMERO, A., Historia de la ciudad de Toledo..., tomo 2, doc. XXVI, p. 1.072. 
inminente guerra en la urbe, hacían cerrar las puertas de las murallas cuando empezaba a anochecer, y si un vecino venía del campo más tarde le obligaban a pagar una buena suma dinero por abrirlas, lo que iba en contra de los privilegios vecinales. Y peor aún era lo que hacía el alcaide del alcázar, Juan de Salazar, que amenazaba a quienes vivían de alquiler junto a su fortaleza con prender fuego a sus viviendas de no irse a vivir a otro lugar. Desconocemos los motivos por los que Salazar actuaba de este modo, pero se sabe que era partidario del conde de Fuensalida y que en los edificios próximos al alcázar vivían amigos del conde de Cifuentes ${ }^{82}$.

En estas circunstancias, el último día de 1506, el jueves 31 de diciembre, los jurados se reunieron para hablar sobre la situación de la urbe. A la asamblea acudieron el bachiller Diego Martínez de Ortega, Diego de Argame, Bernardino de la Higuera, el licenciado Pedro de Herrera, Diego de Rojas, Fernando Vázquez, Tomé Sánchez, Fernando de Vargas, Ruy Pérez de la Fuente, Alfonso de Sosa, Miguel Díaz, Diego Fernández de Madrid y Miguel Ruiz. En nombre suyo y del resto de los jurados escribieron estas palabras tanto para el conde de Fuensalida como para el de Cifuentes y sus respectivas clientelas ${ }^{83}$ :

El Cabildo de los jurados d'esta çibdad de Toledo ha seydo çertificado que non se puede tan prestamente al presente alcançar paz perpetua entre vuestra señoría e sus parientes, e amigos e criados, e entre los otros señores. E que en medio de tregua no quieren venir. E porque ningúnd daño es ni puede ser tamaño ni ygual como romper, porque rompiendo se esperan muchas muertes de buenos $e$ [de] los pobres menudos e total perdiçión e destruyçión d'esta çibdad, por ende, de nuestra parte humillmente suplicamos [...] non dé logar a rompimiento. E sy non se puede asý determinar el medio de la paz, no rehúse ni defeche el medio de la tregua...

Los jurados fueron con esta suplicación a la vivienda del conde de $\mathrm{Ci}$ fuentes, donde lo encontraron con Pedro López de Padilla, Ramiro de Guzmán y Fernando Pérez de Guzmán. Luego vino Tello de Guzmán, Juan de Ayllón, Diego Fernández de Oseguera y otros. No les respondieron; sólo se les contestó que esperasen. Así que afligidos se marcharon a la mansión del conde de Fuensalida. Con él estaban Alonso Téllez Girón, el señor de Cebolla (Diego López de Ayala), el mariscal Payo Barroso de Ribera, Enrique Manrique, Juan Niño, Antonio de la Cueva, Martín Vázquez de Rojas, Antonio Álvarez, Pedro Zapata y otros. Contestaron lo mismo. No obstante,

82 Realmente pone criados, pero se tacha y escribe amigos y allegados: AMT, "Este libro es de traslados...", Sección B, nº 120 , fol. 300 r.

83 Ibidem, fol. 299 r. 
finalmente se llegó a una tregua el 2 de enero de 150784; una tregua que debería durar medio año, hasta junio, hasta el día de San Juan. Los encargados de establecerla fueron el comendador mayor de León (Diego de Cárdenas), el licenciado Gallegos, el prior de San Juan (Álvaro de Zúñiga), el señor de Orgaz y de Santa Olalla (Esteban de Guzmán), el Cabildo catedralicio y algunos hombres buenos ${ }^{85}$. A las pocas horas de certificarse la tregua la esperanza empezó a cundir. Finalmente la paz parecía posible.

El domingo 3 de enero la urbe respiraba más tranquila, pero al día siguiente, el lunes 4, una pelea estuvo a punto de terminar con toda la pacificación. Ocurrió por la tarde, después de $\operatorname{comer}^{86}$. Se arebolvieron dos hombres de a pie sobre una mujercilla de mal vivir dándose de cuchilladas, el uno apellidando Silva y otro Ayala, y juntáronse muchos criados de los señores de las casas, y gritóse por la ciudad en nombre de cada uno, y acudió gran gente y ubo gran brega, aunque plugo a Dios que no hubo más armas que espadas, lanças e apabeses [como se había acordado en la concordia de 1506], con que no dexó aver muertes y heridos. Fue lo más d'este ruido en la plaçuela del conde de Cifuentes, y biendo el conde que yva tan adelante, y que podía suceder gran mal, armóse de todas las armas y sobre un cavallo encubertado salió a poner paz, a tiempo que ya muchos señores avían acudido a lo mismo, quando llegaban ya armas enastadas [...] un escopetero [...] cómo bio salir al conde con un bastón en la mano le apuntó la escopeta allegando la mecha al fogón, y sin duda lo huviera muerto si allí no se allara don Enrique Manrique, hijo del conde de Paredes, que aunque por los Ayala se mostrava, como primo del conde de Fuensalida, arremetió al escopetero y no sólo no le dexó tirar, mas le tiró la escopeta, y ansí escusó tan gran mal que fuera morir tal señor a manos de un hombre soes, que era un esmolador de tijeras de tundir y coxo de una pierna.

Según el cronista Pedro de Alcocer, la pelea la iniciaron dos mozos de espuelas, duró tres horas y en ella hubo varios muertos y heridos. El rey Fernando el Católico, siempre según Alcocer ${ }^{87}$, había establecido que el conde de Cifuentes se encargara de la pacificación de la urbe, y éste, viendo que los de Pedro López de Padilla subían a Zocodover y que se preparaba un escándalo, salió armado a sosegar el conflicto, para que no fuesen viudas artas mujeres [...] si el conde de Cifuentes tardara media hora la parte de los de Ayala

84 AHN, Osuna, leg. 1, no 26; BENITO RUANO, E., Toledo en el siglo XV..., doc. 98, pp. 311-312.

85 AMT, "Este libro es de traslados...", Sección B, nº 120, fol. 357 r-v; Real Academia de la Historia, Colección Salazar y Castro, sig. 9/234, fols. 310 v-312 r.

86 Real Academia de la Historia, Colección Salazar y Castro, sig. 9/234, fols. 310 v-312 r.

87 ALCOCER, P. de, Relación de algunas cosas que pasaron en estos reinos..., pp. 20-22. 
librara mal, porque [...] la gente de Pedro López de Padilla que estaba alojada en el castillo de San Servan, que su hermano el comendador mayor de Calatrava la había enviado, que eran quatrocientos peones y ochenta de a cavallo, aunque era despedida [venía a la urbe, y] ya éstos llegando a Zocodover les dejó mandado que se volviesen, que ya había paz, y ansí se escapó de ser...i ? El cronista no acabó la frase, sino que al final dejó unos puntos suspensivos muy elocuentes que Martín Gamero remarcaría en su edición del texto en el siglo XIX. A nota a pié de página Gamero se preguntaba si tal vez en los referidos puntos no deberían de leerse estas palabras: escapó de ser "muerto el conde de Fuensalida". Aunque sea una reflexión brusca es indudable que los enfrentamientos habían llegado a un radicalismo que no se recordaba. Aprovechando el alboroto, sin ir más lejos, unos hombres fueron a las viviendas de los mercaderes Francisco Sánchez ${ }^{88}$ y Juan de Rojas ${ }^{89}$ y las saquearon.

Posteriores documentos nos indican que en la pelea del 4 de enero de 1507 mataron al menos a 6 hombres y 80 salieron heridos ${ }^{90}$. Ese mismo día por la noche el conde de Cifuentes llegó a un acuerdo con el comendador mayor de León basado en tres puntos ${ }^{91}$ :

$1^{\circ}$. El individuo que viniese de la corte para pacificar Toledo, fuera quien fuera, tendría a su servicio a los soldados de la capitanía del adelantado de Granada, es decir, a los soldados del propio comendador Diego de Cárdenas, y a los hombres de la capitanía del conde de Cifuentes (alférez real), para que con ellos defendiera el orden público. De la misma forma, el arzobispo toledano también ordenaría a su séquito que ayudase al juez de la corte.

$2^{\circ}$. Dicho juez debía ser aprobado por el arzobispo de Toledo y por el duque de Alba.

$3^{\circ}$. El pesquisydor que está (Gonzalo de Gallegos, llegado a la urbe un poco antes) o el jues que viniere se conçierte con los governadores de las órdenes de Santiago y Calatrava secretamente para que le favorescan cada ves que los oviere menester y los llamare.

Manifestando una indiscutible inteligencia, a inicios de 1507 fue el conde de Cifuentes el que comenzó a actuar, una vez que los Ayala parecían quedarse sin argumentos. El líder de los Silva logró que el rey Fernando le encargara la tarea de pacificar Toledo junto a la persona que se iba a enviar desde la corte; una Toledo en la que -según la información que nos se conserva- en los primeros días de 1507 estaban aparejados otros mayores escándalos e yn-

88 AGS, RGS, 1507-I, Salamanca, 8 de enero de 1506 (léase de 1507).

89 AMT, "Este libro es de traslados...", Sección B, nº. 120, fols. 306 r- 307 r.

90 AGS, RGS, 1507-I, Palencia, 30 de enero de 1507.

91 Real Academia de la Historia, Colección Salazar y Castro, sig. A-12, fol. 193. 
convenites de los que había habido ${ }^{92}$. Sobre toda la población se cernía por entonces la amenaza de la lucha de bandos, esa que en los años 1460 y 1470 había producido el caos. Era como si de repente el reinado de los Reyes Católicos no hubiese existido, como si la paz que habían impuesto fuera sólo un paréntesis en la historia de una urbe condenada a enfrentarse a sí misma y a vivir dividida. Por suerte, en 1506 y 1507 al menos se evitó el rompimiento. A partir de esas fechas la ciudad viviría unos años de calma tensa, hasta que en 1520 no sólo la estabilidad se rompió, sino que la ruptura fue decisiva en muchos sentidos, dando lugar a un tipo de insurrección que para no pocos de los historiadores más reputados sería la primera de los tiempos modernos.

92 AGS, RGS, 1507-I, Burgos, 10 de enero de 1507. 